RESEARCH PAPER RP1511

Part of Journal of Research of the National Bureau of Standards, Volume 29, December 1942

\title{
ANALYSIS OF THE SELECTIVE COMBINATION OF WOOL WITH ACIDS IN MIXTURES
}

\author{
By Jacinto Steinhardt ${ }^{1}$
}

\section{ABSTRACT}

Wool immersed in mixtures of two strong acids, or of one acid and a salt of a second, combines with these acids in unequal amounts. The present paper demonstrates that the results obtained with mixtures may be predicted with fair approximation from the anion-wool dissociation constants previously assigned to each anion on the basis of titration data. Methods are described for calculating the total acid and the relative proportions of each which are bound. Conversely, it is also shown that approximate values of the dissociation constants may be calculated from the results of experiments with mixtures.

\section{CONTENTS}

I. Introduction $\ldots \ldots \ldots \ldots$

II. Basis of the calculations

III. Analysis of the experimental data

1. Total acid bound in mixtures of two acids _........... 427

2. Selective combination of anions in mixtures of two acids _ _ _ 431

3. Estimation of anion affinities from experiments with mixtures_. _ 433

4. Mixtures of a dye salt and an acid _._.

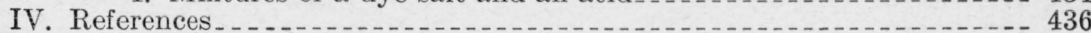

\section{INTRODUCTION}

It is shown elsewhere that wool, immersed in mixtures of two strong acids, or of one acid and a salt of a second, combines with these acids in unequal amounts [6]. ${ }^{2}$ When present in initially equimolar mixtures with either hydrochloric acid or naphthalenesulfonic acid, such a dye as Orange II is transferred from the solution to the fibers more completely than when the dye acid alone is used. This effect is more pronounced in the presence of hydrochloric acid, which has a very low affinity for the fibers $[1,4,5]$, than with naphthalenesulfonic acid, which has a considerably higher tendency itself to combine with wool. In fact, with high ratios of naphthalenesulfonic to dye acid, the exhaustion of the dye from the solution is reduced rather than increased.

Interest attaches to these measurements not only because of their bearing on the control of dye exhaustion, but also because it has been shown that differences in the level dyeing properties of these mixtures accompany the differences in their tendencies to transfer dye to the wool [6]. It is the purpose of the present paper to show that these measurements are consistent with the theory which was developed to explain the differences between titration curves of wool obtained with

1 Research Associate at the National Bureau of Standards, representing the Textile Foundation.

2 Figures in brackets indicate the literature references at the end of this paper. 
different single acids. Thus, it is shown here that the results obtained with mixtures may be predicted with fair approximation from the anion-protein dissociation constants, previously assigned to each anion on the basis of titration data. Conversely, it is also shown that approximate values of these dissociation constants may be calculated from the results of experiments with mixtures.

\section{BASIS OF THE CALCULATIONS}

When wool is allowed to attain equilibrium with a dilute solution of an acid, the amount combined (given as a fraction of the maximum of about $0.83 \mathrm{mmole} / \mathrm{g}$ ) is described with good approximation [2] by the equation

$$
\frac{\text { Amount combined }}{\text { Maximum combined }} \equiv \frac{B}{T}=\frac{1}{1+\left(\frac{K_{\mathrm{A}}}{a_{\mathrm{H}}}\right)^{1 / 2}\left[\frac{a_{\mathrm{H}}^{1 / 2}+\left(K_{\mathrm{H}}\right)^{1 / 2}}{a_{\mathrm{H}}{ }^{1 / 2}+\left(K_{\mathrm{H}}\right)^{1 / 2}}\right]},
$$

in which $a_{\mathrm{H}}$ represents the activity of hydrogen ions and the $K^{\prime} \mathrm{s}$ are mass-law constants characterizing the following dissociation processes

$$
\begin{array}{ll}
K_{\mathrm{A}}, & \mathrm{WHA} \rightleftharpoons \mathrm{WH}^{+}+\mathrm{A}^{-} \\
K_{\mathrm{H}}^{\prime} & \mathrm{WHA} \rightleftharpoons \mathrm{WA}^{-}+\mathrm{H}^{+} \\
K_{\mathrm{H}} & \mathrm{WH}^{+} \rightleftharpoons \mathrm{W}^{*}+\mathrm{H}^{+},
\end{array}
$$

in which $\mathrm{W}^{ \pm}, \mathrm{WH}^{+}$, etc., represent ionic states of wool. The interrelations between these three dissociation constants and one other, $K_{\mathrm{A}}{ }^{\prime}$, which characterizes another equilibrium

$$
K_{\mathrm{A}}^{\prime}, \quad \mathrm{WA}^{-} \rightleftharpoons \mathrm{W}^{ \pm}+\mathrm{A}^{-}
$$

have been discussed elsewhere $[1,2,4]$. Equation 1 was derived by combining these equilibria and defining $B / T$ as

$$
[\mathrm{WHA}]+\left[\mathrm{WA}^{-}\right]
$$

$\frac{\left[\mathrm{WHA}^{-}\left[\mathrm{WA}^{-}\right]\right.}{[\mathrm{WHA}]+\left[\mathrm{WA}^{-}\right]+\left[\mathrm{WH}^{+}\right]+\mathrm{W}^{ \pm}}$, on the basis of assumptions discussed elsewhere [2].

In experiments involving two different anions, two sets of anionprotein dissociations must be distinguished. This will be done by writing $K_{1}^{\prime}$ and $K_{2}^{\prime}$ for the constants determining the equilibria involving the anions $A_{1}$ and $A_{2} . \quad a_{1}$ and $a_{2}$ represent the activities of these anions. The anion common to all of the experiments, Orange II, will always be characterized as $A_{2}$. By combining the six possible equilibria involving wool, two anions, and hydrogen ion, one may derive an expression for the total acid combined, as a fraction of the total possible combination of acids, by defining the following identity: Fraction of maximum bound

$$
\begin{aligned}
& \equiv \frac{B}{T} \equiv \frac{\left[\mathrm{WHA}_{1}\right]+\left[\mathrm{WHA}_{2}\right]+\left[\mathrm{WA}_{1}{ }^{-}\right]+\left[\mathrm{WA}_{2}{ }^{-}\right]}{\left[\mathrm{WHA}_{1}\right]+\left[\mathrm{WHA}_{2}\right]+\left[\mathrm{WA}_{1}{ }^{-}\right]+\left[\mathrm{WA}_{2}{ }^{-}\right]+\left[\mathrm{WH}^{+}\right]+\left[\mathrm{W}^{ \pm}\right]} \\
& =\frac{1}{1+\frac{\left(K_{1^{\prime}} K_{2}{ }^{\prime}\right)^{1 / 2}}{\left(a_{1} K_{2}{ }^{1 / 2}+\left(a_{2} K^{\prime}{ }_{1}\right)^{1 / 2}\right.}\left[\frac{\left(K_{\mathrm{H}}\right)^{1 / 2}}{\left.K_{\mathrm{H}^{\prime}}\right)^{1 / 3}} \cdot \frac{\left(a_{\mathrm{H}}\right)^{1 / 2}+\left(K_{\mathrm{H}}\right)^{1 / 2}}{\left(a_{\mathrm{H}}\right)^{1 / 2}+\left(K_{\mathrm{H}}{ }^{1 / 2}\right)^{1 / 2}}\right]}
\end{aligned}
$$

In the remainder of this paper the bracketed expression in the denominator will be written $f\left(a_{\mathrm{H}}\right){ }^{3}$

\footnotetext{
It is sometimes useful to express $B / T$ in terms of the ratio $\left(\begin{array}{l}K_{1} \\ K_{2}\end{array}\right) 1 / 2$ hereafter designated $\rho$. Thus, for ex-
ample:

$$
\frac{B}{T}=\frac{1}{1+\frac{\left(K_{1}\right)^{1 / 2}}{a_{1}^{1 / 2}+\rho\left(a_{\mathrm{B}}-a_{1}\right)^{1 / 2}} f\left(a_{\mathrm{a}}\right)}\left(2^{\prime \prime}\right)
$$

This rearrangement shows (cp. with ea $1^{\prime}$ ) that in the presence of a large excess of the acid of lower affinity, the position of the mixed titration curve approaches that characterizing the combination of wool with the latter acid alone.
} 


\section{ANALYSIS OF THE EXPERIMENTAL DATA}

A quantitative comparison of the theoretical expectations with the results of experiments may have any or all of three purposes: to establish the validity of the reasoning and of the premises upon which the theoretical expectations are based (in this case, the concept of reversible anion-protein association); to establish, for practical purposes, a basis for predicting the effects of variations of certain experimental quantities (prediction of the effect, on the degree of exhaustion of the dyebath, of the amounts or the nature of the acids, dyes, and other substances present); or finally, to derive from the experimental data numerical values of the natural constants which may be involved (to determine affinity constants from the results of experiments with mixtures of anions). The present calculations deal with all three of these purposes; however, because of the complexity of the relations among the many variables involved, it is more convenient to serve each of these purposes separately.

\section{TOTAL ACID BOUND IN MIXTURES OF TWO ACIDS}

The first purpose of these calculations, as listed above, may be accomplished, in part, by showing that the amounts of hydrogen ion and of each of two anions combined by wool can be estimated directly

TABLE 1.-Combination of wool at $50^{\circ} \mathrm{C}$ with two acids initially present in equimolar proportions

[1. $04 \mathrm{~g}$ of dry wool to $100 \mathrm{ml}$ of solution]

\begin{tabular}{|c|c|c|c|c|c|c|c|c|}
\hline $\begin{array}{l}\text { Initial concen- } \\
\text { tration of each } \\
\text { acid }\end{array}$ & $\begin{array}{c}\text { Final } \\
\mathrm{pH}\end{array}$ & $\begin{array}{c}\text { Total acid } \\
\text { neutral- } \\
\text { ized }\end{array}$ & $\begin{array}{l}\text { Ammonia } \\
\text { evolved }\end{array}$ & $\begin{array}{l}\text { Total acid } \\
\text { combined }\end{array}$ & $\begin{array}{c}\text { Dye com- } \\
\text { bined }\end{array}$ & $\begin{array}{l}2 \mathrm{~d} \text { anion } \\
\text { combined } \\
\text { (by diff- } \\
\text { ference) }\end{array}$ & \multicolumn{2}{|c|}{ Dye not combined } \\
\hline \multicolumn{9}{|c|}{ A. Orange II plus hydrochloric acid } \\
\hline $\begin{array}{c}\text { Moles/liter } \\
10.025 \\
.015 \\
.010 \\
.007 \\
.005 \\
.0035 \\
.0023 \\
.0016 \\
.0011 \\
.0007 \\
.0004\end{array}$ & $\begin{array}{l}1.50 \\
1.78 \\
2.04 \\
2.24 \\
2.42 \\
2.63 \\
2.94 \\
3.14 \\
3.40 \\
3.71 \\
4.20\end{array}$ & 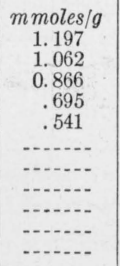 & 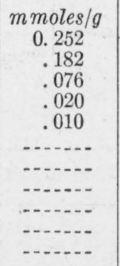 & $\begin{array}{c}m \text { moles/g } \\
0.945 \\
.880 \\
.790 \\
.675 \\
.531 \\
.410 \\
.287 \\
.236 \\
.157 \\
.128 \\
.073\end{array}$ & $\begin{array}{c}\text { mmoles/g } \\
0.96 \\
.93 \\
.864 \\
.670 \\
.483 \\
.388 \\
.223 \\
.155 \\
.107 \\
.067 \\
.037\end{array}$ & $\begin{array}{c}\text { mmoles/g } \\
-0.015 \\
-.05 \\
-.074 \\
+.005 \\
.048 \\
.072 \\
.050 \\
.081 \\
.050 \\
.061 \\
.036\end{array}$ & 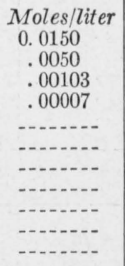 & $\begin{array}{c}\% \\
60.0 \\
33.3 \\
10.3 \\
1.0 \\
-.- \\
-.- \\
-.- \\
-- \\
-.- \\
-.\end{array}$ \\
\hline \multicolumn{9}{|c|}{ B. Orange II plus naphthalene- $\boldsymbol{\beta}$-sulfonic acid } \\
\hline $\begin{array}{l}0.025 \\
.015 \\
.010 \\
.007 \\
.005 \\
.0035 \\
.0023 \\
.0016 \\
.0011 \\
.0007 \\
.0004\end{array}$ & $\begin{array}{l}1.55 \\
1.82 \\
2.08 \\
2.34 \\
2.65 \\
2.98 \\
3.32 \\
3.62 \\
3.89 \\
4.32 \\
4.72\end{array}$ & 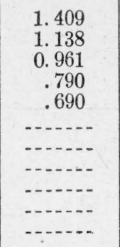 & 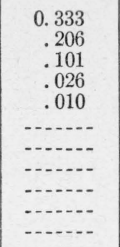 & $\begin{array}{l}1.076 \\
0.932 \\
.860 \\
.764 \\
.680 \\
.535 \\
.365 \\
.258 \\
.175 \\
.113 \\
.057\end{array}$ & $\begin{array}{l}1.097 \\
0.924 \\
.820 \\
.656 \\
.482 \\
.338 \\
.222 \\
.154 \\
.106 \\
.068 \\
.039\end{array}$ & $\begin{array}{r}-0.014 \\
+.008 \\
.040 \\
.108 \\
.198 \\
.197 \\
.145 \\
.104 \\
.069 \\
.035 \\
.018\end{array}$ & $\begin{array}{l}0.0137 \\
.00542 \\
.00151 \\
.00021 \\
.000062 \\
.000015 \\
.0000058 \\
.0000025 \\
-. .-- \\
-. .-\end{array}$ & \begin{tabular}{r}
54.9 \\
36.1 \\
15.1 \\
2.9 \\
1.2 \\
0.4 \\
.3 \\
.2 \\
\hdashline..- \\
... \\
..-
\end{tabular} \\
\hline
\end{tabular}

1 The initial concentration of hydrochloric acid in this single case was 4 percent lower than the dye concentration. 
from the amounts of each of two acids, or their salts, present at equilibrium, and from the several dissociation constants involved (presumed to have been measured independently). This requirement involves merely the application of eq $2^{\prime}$ to the experimental data already described in part in another paper [6], and given more fully in tables 1,2 , and 3 .

Such a test of theory is neither as broad nor as useful as it might be, because the concentrations of the two anions at equilibrium are not truly independent variables (i.e., cannot be controlled simply at the will of the experimenter), but are fixed, in part, by the anionprotein equilibrium constants. Since the latter also figure directly in the calculation, the quantities $a_{1}$ and $a_{2}$ of eq $2^{\prime}$ are introduced somewhat redundantly. A treatment formulated in terms of the initial quantities and the dissociation constants would be both more elegant and more useful, because the initial concentrations, $\mathbf{A}_{1}$ and $\mathbf{A}_{2}$, rather than the final concentrations, $a_{1}$ and $a_{2}$, are directly controlled, not only in the present experiments, but in practical dyeing as well. However, an analysis in terms of equilibrium concentrations, though less useful, is easier.

TABLE 2.-Combination of wool, at $50^{\circ} \mathrm{C}$, with two acids, one of which was initially present to 10 times the amount of the other

[In A, $1.033 \mathrm{~g}$ of dry wool were used with $100 \mathrm{ml}$ of solution.

In $\mathrm{B}, 0.87 \mathrm{~g}$ of dry wool were used to $75 \mathrm{ml}$ of solution]

\begin{tabular}{|c|c|c|c|c|c|c|c|}
\hline $\begin{array}{l}\text { Initial concen- } \\
\text { tration of dye }\end{array}$ & $\underset{\mathrm{pH}}{\text { Final }}$ & $\begin{array}{c}\text { Total acid } \\
\text { neutral- } \\
\text { ized }\end{array}$ & $\begin{array}{l}\text { Ammonia } \\
\text { evolved }\end{array}$ & $\begin{array}{l}\text { Total acid } \\
\text { combined }\end{array}$ & $\begin{array}{l}\text { Dye com- } \\
\text { bined }\end{array}$ & $\begin{array}{l}\text { 2d anion } \\
\text { combined } \\
\text { (by differ- } \\
\text { ence) }\end{array}$ & Dye not combined \\
\hline
\end{tabular}

A. Orange II (1) plus hydrochloric acid (10)

\begin{tabular}{|c|c|c|c|c|c|c|c|c|}
\hline $\begin{array}{c}\text { moles/liter } \\
0.010 \\
.007 \\
.005 \\
.0035 \\
.0023 \\
.0016 \\
.0011 \\
.0007 \\
.0004 \\
.0002\end{array}$ & $\begin{array}{l}1.09 \\
1.24 \\
1.40 \\
1.58 \\
1.80 \\
1.98 \\
2.20 \\
2.46 \\
2.78 \\
3.26\end{array}$ & $\begin{array}{r}\text { mmoles } / g \\
1.160 \\
0.902 \\
.825 \\
.754 \\
.660 \\
\end{array}$ & $\begin{array}{r}\mathrm{mmoles} / \mathrm{g} \\
0.248 \\
.080 \\
.040 \\
.022 \\
.010 \\
\end{array}$ & $\begin{array}{r}\text { moles/g } \\
0.912 \\
.822 \\
.785 \\
.733 \\
.650 \\
.562 \\
.456 \\
.341 \\
.223 \\
.092\end{array}$ & $\begin{array}{r}\text { mmoles/g } \\
0.930 \\
.672 \\
.481 \\
.337 \\
.222 \\
.154 \\
.106 \\
.068 \\
.039 \\
.019\end{array}$ & $\begin{array}{r}\text { mmoles/g } \\
-0.018 \\
+.150 \\
.304 \\
.396 \\
.428 \\
.408 \\
.350 \\
.273 \\
.184 \\
.073\end{array}$ & $\begin{array}{r}\text { moles/liter } \\
0.000329 \\
.000050 \\
.000015 \\
.000005 \\
\end{array}$ & $\begin{array}{r}{ }^{\%} .3 \\
.7 \\
.3 \\
.1 \\
\\
\\
\\
\\
\end{array}$ \\
\hline
\end{tabular}

B. Orange II (1) plus naphthalene- $\boldsymbol{\beta}$-sulfonic acid (10)

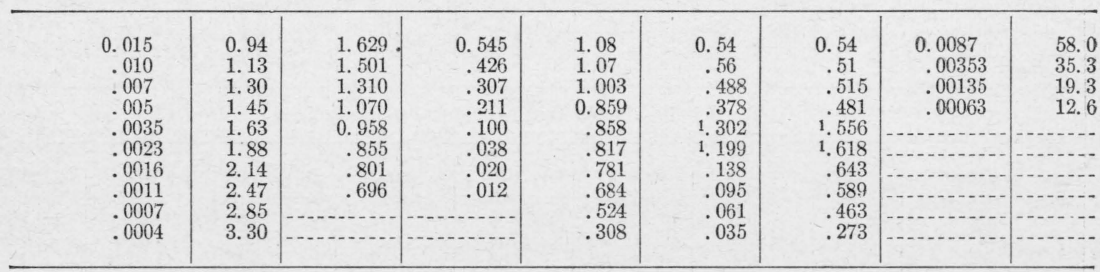

1 Based on combination with all dye present. The dye remaining uncombined was too dilute to be read accurately in the colorimeter, although color was visible. The figure given for dye combined is therefore high, possibly by as much as 0.01 to $0.02 \mathrm{mmole} / \mathrm{g}$. The figures for naphthalenesulfonate combined may therefore be correspondingly low. 
TABLE 3.-Combination of wool, at $50^{\circ} \mathrm{C}$, with two anions initially present in nearly equimolar proportions with hydrogen ion

In the experiment marked with an asterisk the initial acid concentration was 3 percent higher than the initial dye salt concentration. $1.04 \mathrm{~g}$ of dry wool in $100 \mathrm{ml}$ of solution, except for experiments marked $t$, in which $0.87 \mathrm{~g}$ of wool were immersed in $75 \mathrm{ml}$ of solution]

\begin{tabular}{c|c|c|c|c|c|c|c|}
\hline \hline $\begin{array}{c}\text { Initial concen- } \\
\text { tration of dye }\end{array}$ & $\begin{array}{c}\text { Final } \\
\mathrm{pH}\end{array}$ & $\begin{array}{c}\text { Total acid } \\
\text { neutral- } \\
\text { ized }\end{array}$ & $\begin{array}{c}\text { Ammonia } \\
\text { evolved }\end{array}$ & $\begin{array}{c}\text { Total acid } \\
\text { combined }\end{array}$ & $\begin{array}{c}\text { Dye anion } \\
\text { ion com- } \\
\text { bined } \\
\text { bined (by } \\
\text { differ- } \\
\text { ence) } 1\end{array}$ & Dye not combined \\
\hline
\end{tabular}

A. Orange II (sodium salt) plus hydrochloric acid

\begin{tabular}{|c|c|c|c|c|c|c|c|c|}
\hline moles/liter & & mmoles $/ g$ & mmoles $/ g$ & mmoles $/ g$ & mmoles/g & mmoles/g & moles/liter & $\%$ \\
\hline 0.0291 & 1.82 & 1.070 & 0.145 & 0.925 & 0.982 & 0.057 & 0.0187 & 64.2 \\
\hline .0194 & 2.10 & .973 & .090 & $\begin{array}{r}.820 \\
.883\end{array}$ & $\begin{array}{r}.970 \\
.970\end{array}$ & .087 & .00916 & 47.2 \\
\hline 0145 & 2. 35 & .893 & .046 & .847 & .890 & .043 & .00495 & 33.1 \\
\hline .00970 & 2. 94 & .800 & .020 & .780 & .823 & .043 & .00105 & 10.8 \\
\hline .00727 & 3. 44 & .637 & .010 & .627 & .661 & 034 & 00033 & 4. 6 \\
\hline+.00480 & 4. 01 & & $\ldots .$. & .405 & .406 & .001 & .00010 & 2.0 \\
\hline+.00352 & 4. 15 & & & .293 & .300 & .007 & .00006 & 1. 7 \\
\hline .0020 & 4. 62 & & & .200 & .194 & -.006 & . & $\cdots$ \\
\hline .00125 & 4. 86 & - & - non & .114 & .121 & .007 & .00001 & 1. 2 \\
\hline$\dagger^{*} .0010$ & 4. 71 & - n & . & .082 & .086 & .004 & .00001 & 1.0 \\
\hline .00075 & 5. 18 & - n & n. & .067 & .073 & .006 & - n & $\ldots . .$. \\
\hline .00050 & & $\ldots$ & $\ldots$. & .041 & .049 & .008 & & \\
\hline
\end{tabular}

B. Orange II (Sodium Salt) plus naphthalene- $\boldsymbol{\beta}$-sulfonic acid

\begin{tabular}{|c|c|c|c|c|c|c|c|c|}
\hline 0.0291 & 1.82 & 1. 024 & 0.143 & 0.881 & 0.875 & ${ }^{2}-0.006$ & 0.02003 & 69.0 \\
\hline .0194 & 2. 09 & 925 & .086 & .839 & .880 & +.041 & 01023 & 52.8 \\
\hline 0145 & 2. 34 & 902 & 048 & .854 & .840 & -.014 & .00575 & 39.6 \\
\hline .00970 & 2. 97 & .800 & .014 & .786 & .752 & -.024 & .00186 & 19. 2 \\
\hline .00727 & 3. 54 & & - & .654 & .605 & -.049 & .00120 & 16. 5 \\
\hline .00485 & 4. 30 & & $\ldots$ & .451 & .420 & -.031 & .000475 & 9.8 \\
\hline †. 00480 & 4. 54 & $\ldots$ & ..... & .408 & .378 & -.030 & .000432 & 9.0 \\
\hline †. 00352 & 4. 73 & $\ldots$ & - n & .408 & 282 & -.016 & 000264 & 7.5 \\
\hline .00320 & 4. 70 & & & .295 & .283 & -.012 & .000262 & 8. 2 \\
\hline 00194 & 5.06 & & $\ldots$ & .182 & .172 & -.010 & .000145 & 7.5 \\
\hline .00121 & 5. 27 & $\ldots$ & $\ldots$ & .111 & .109 & -.002 & .000067 & 5. 6 \\
\hline †. 00100 & 5.35 & - & - & .079 & .072 & -.007 & .000045 & 4.5 \\
\hline .00073 & 5.41 & $\ldots$ & $\ldots \ldots$ & .066 & .066 & .000 & .000040 & 5. 5 \\
\hline
\end{tabular}

1 Measurements showed that no detectable quantity of chloride ion was combined.

2 Negative values in this column indicate that more naphthalenesulfonate ions than sodium ions were combined, but do not necessarily give the amount of naphthalenesulfonate combined.

In earlier work involving combination with a single anion, the concentration or activity of each ion was determined from the $\mathrm{pH}$ or, when salts were present, from the $\mathrm{pH}$ and the predetermined level at which the anion concentration was held constant. In the present experiments, with two acids, analogous information may be obtained from the $\mathrm{pH}$ and the colorimetric estimation of residual dye anion; if, in addition, total dissociation may be assumed, and concentrations may be freely substituted for activities, the concentration of the second anion may be obtained from the relation $\left[\mathrm{H}^{+}\right]=\left[\mathrm{A}_{1}\right]+\left[\mathrm{A}_{2}\right]$. The validity of this relation depends not only upon the assumptions just stated, best approximated in very dilute solutions, but also is affected by the presence of cations other than hydrogen ion. ${ }^{4}$

The correctness with which eq $2^{\prime}$ describes the data obtained with mixtures may be tested by calculating $B / T$ (total acid bound) for any of the sets of data in tables 1 to 3 making use only of the $\mathrm{pH}$ values and the values of $a_{2}$ (dye not combined). Only the data in table 1 (B),

\footnotetext{
4 These cations may be from the ash in the fibers, or may be produced by decomposition of the wool. When ammonia alone is produced, the relation becomes $[\mathrm{H}+]+\left[\mathrm{NH}_{4}\right]=\left[\mathrm{A}_{1}\right]+\left[\mathrm{A}_{2}\right]$. The neglect of ash and of traces of other decomposition products of the wool, when using this relation, affects many of the calculations in this paper, to some degree.
} 
however, permit a significant comparison with the equation, since $a_{2}$ (to which the equation is sensitive) can be estimated with accuracy only when the exhaustion of the solution is not too extreme. When salt is present (table 3), the degree of exhaustion is not high but the calculation of $a_{1}$ presents difficulties. With these parameters, and the constants previously reported $\left(K_{\mathrm{H}}{ }^{\prime}=0.0000932 ; K_{1}{ }^{\prime}=0.0208\right.$; $\left.K_{2}{ }^{\prime}=0.000232\right)$, theoretical values of the total acid bound have been computed and are represented graphically by the broken line in figure 1. For purposes of comparison, the amount of each of the two acids which are combined by wool when the acids are not mixed are also represented. It is clear that the results predicted by eq $2^{\prime}$

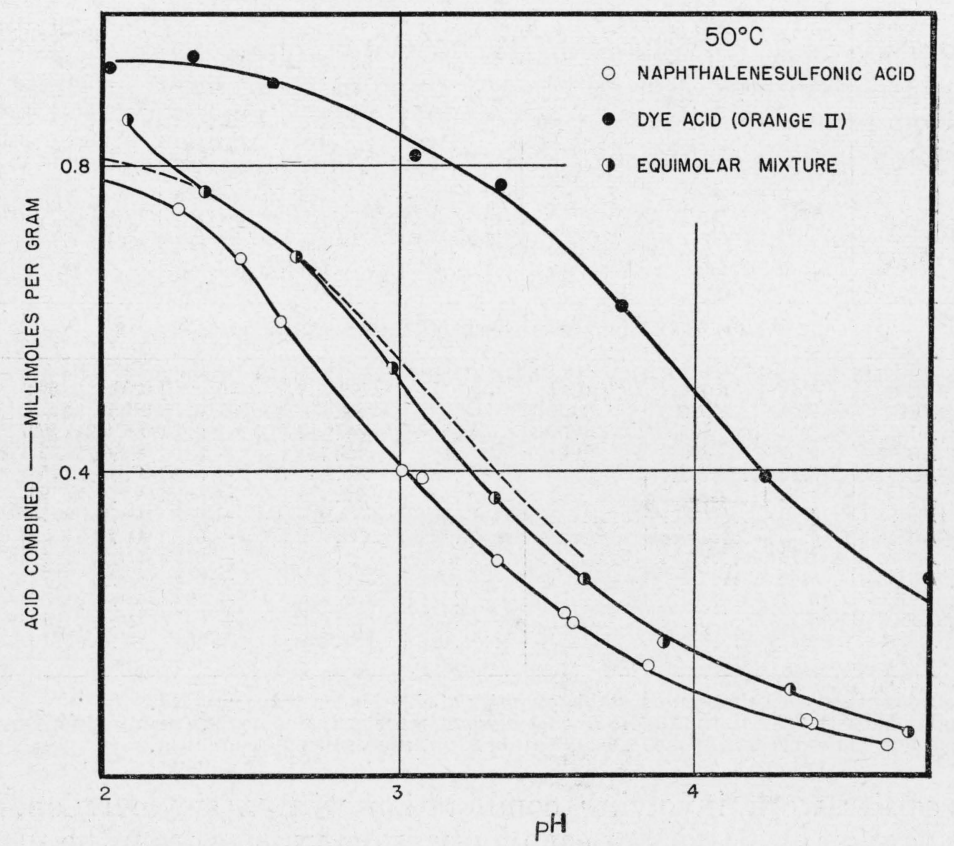

Figure 1.-Total acid combined by wool, as a function of $p \mathrm{H}$, in initially equimolar mixtures of naphthalene- $\beta$-sulfonic acid and the dye acid, Orange II.

The results obtained with each acid alone are included for comparison. The broken line represents eq $2^{\prime}$.

come very close to the experimental values over a wide range of the data. The most serious discrepancy, at the top of the figure, is due to the fact that more acid may be combined than the amount, 0.83 mmole/g, which has been taken as the maximum for the particular mechanism of combination represented by our equations. This excess combination, the cause of which has been discussed elsewhere $[4,5]$, will result in similar discrepancies when amounts over about $0.7 \mathrm{mmole} / \mathrm{g}$ are bound, in all similar comparisons of theory and experiment in the present paper.

Just as the mechanizm of combination with these "excess" amounts is left out of consideration here, the separate mechanism of combination for very small amounts, by means of combination with histidine residues, is also neglected [3]. In this case the amounts involved are 
so small that combination of hydrogen ions with imidazole groups has been lumped together with combination of hydrogen ions with carboxylate groups, and expressed in the same constant.

\section{SELECTIVE COMBINATION OF ANIONS IN MIXTURES OF TWO ACIDS}

The fulfillment of the second purpose of these calculations (p. 427) also furnishes a further test of the concepts underlying the derivation of eq $2^{\prime}$. The ratio, $r$, of the amounts bound of the two different anions is

$$
r=\frac{\left[\mathrm{WHA}_{1}\right]+\left[\mathrm{WA}_{1}-\right]}{\left[\mathrm{WHA}_{2}\right]+\left[\mathrm{WA}_{2}-\right]}=\left(\frac{a_{1}}{a_{2}} \cdot \frac{K_{2}^{\prime}}{K_{1}^{\prime}}\right)^{1 / 2} .
$$

This relation may be tested on the data in tables 1 and 2. Where no accurate estimates of $a_{2}$ and $a_{1}$ are given in these tables, $a_{1}$ may be calculated from the $\mathrm{pH}$ and from $[T-B]$, defined as the part of the wool which is not combined with acid. ${ }^{5}$

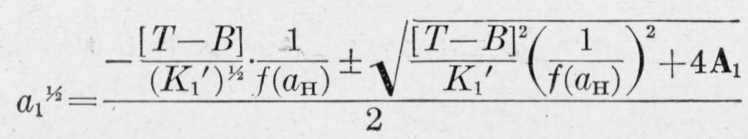

This relation is valid only if concentrations and activities may be freely interchanged. $(T-B)$ must be converted from millimoles per gram of wool into units which refer to equivalent concentrations of acid in the solution.

By combining 3 and 4, an expression for $r$ is obtained which depends on $(T-B), a_{\mathrm{H}}$, and on the initial amounts of the two acids, $\mathbf{A}_{1}$ and $\mathbf{A}_{2}$ :

$$
r=\frac{K_{2}^{\prime}}{K_{1}^{\prime}} \frac{1-\sqrt{1+\frac{4 \mathbf{A}_{1} K_{1}{ }^{\prime}}{(T-B)^{2}} f^{2}\left(a_{\mathrm{H}}\right)}}{1-\sqrt{1+\frac{4 \mathbf{A}_{2} K_{2}{ }^{\prime}}{(T-B)^{2}} f^{2}\left(a_{\mathrm{H}}\right)}}
$$

It is obvious that in the limiting case of very high $a_{\mathrm{H}}, r$ is determined by the ratios of the initial amounts, $\mathbf{A}_{1} / \mathbf{A}_{2}$, and of the $K$ 's. At this limit $K_{\mathrm{A}}{ }^{\prime}$ for an unfamiliar anion could be determined at once if the other constant were known. Unfortunately, a clear-cut limit is never realized because of the additional combination with acid which sets in at low $\mathrm{pH}$.

A third and most direct method of calculating $r$ is to calculate the actual amounts of each anion bound:

$$
r=\frac{\mathbf{A}_{1}-a_{1}}{\mathbf{A}_{2}-a_{2}}
$$

where $a_{1}$ and $a_{2}$ are given by eq 4 .

In tables 4 and 5 are summarized the results of the three types of computations just described, for three of the experiments with mixtures of two acids. In the fourth experiment the amounts of the

$3[T-B]=\left[\mathrm{WH}^{+}\right]+\left[\mathrm{W}^{ \pm}\right]=\left[\mathrm{W}^{ \pm}\right]\left(\frac{a_{\mathrm{H}^{1 / 2}}+K_{\mathrm{H}^{1 / 2}}}{K_{\mathrm{H}^{1 / 2}}}\right)$. Equation 4 is derived by combining this relation with $a_{1}=\mathbf{A}_{1}-\left[\mathrm{WHA}_{1}\right]-\left[\mathrm{WA}_{1}^{-}\right]$. 
second acid bound are too small to permit a significant comparison with theory. $r$ itself has not been tabulated, but the total amount of acid bound and $r$, as calculated from the equations above, have been combined to give the amount of the second acid bound. This facilitates graphical comparison with the experimental values. In table 4 the first column under naphthalenesulfonic acid bound gives the experimental value; the other columns give the values calculated by each of the methods described above. It is apparent that all of the methods give comparable results and that most of these results are fairly close to the experimental values. This comparison is made clearer in figure 1 of an earlier paper [6], in which the values given by eq 4 and 5 are plotted together with the experimental data. The values obtained from the equations all tend to be higher than those found experimentally, but they agree in their general trend and in the position, with respect to the $\mathrm{pH}$ coordinate, of the maximum amount bound. The closeness of the agreement between experiment and theory can best be indicated by noting that a difference of $0.08 \mathrm{pH}$ unit in the position of the titration curve for naphthalenesulfonic acid alone would have given a value of $K_{\mathrm{A}}{ }^{\prime}$ such that the agreement of experiment and theory would have been almost perfect.

TABLE 4.-Comparison of data obtained with equimolecular mixtures of naphthatenesulfonic acid and Orange II, with calculated values

\begin{tabular}{|c|c|c|c|c|c|c|}
\hline \multirow[b]{2}{*}{$\mathrm{pH}$} & \multirow[b]{2}{*}{$\begin{array}{l}\text { Total } \\
\text { a mount } \\
\text { of acid } \\
\text { bound }\end{array}$} & \multicolumn{5}{|c|}{ Naphthalenesulfonic acid bound } \\
\hline & & $\begin{array}{l}\text { Experi- } \\
\text { mental }\end{array}$ & $\begin{array}{c}\text { Calculated } \\
\text { by eq } 3\end{array}$ & $\begin{array}{c}\text { Calculated } \\
\text { by eq } 5\end{array}$ & $\begin{array}{c}\text { Calculated } \\
\text { with value } \\
\text { of } a_{1} \\
\text { given by } \\
\text { eq } 4\end{array}$ & $\begin{array}{c}\text { Calculated } \\
\text { by eq } 6\end{array}$ \\
\hline $\begin{array}{l}2.34 \\
\text { 2. } 65 \\
2.98 \\
\text { 3. } 32 \\
\text { 3. } 62 \\
\text { 3. } 89 \\
\text { 4. } 32 \\
\text { 4. } 72\end{array}$ & $\begin{array}{c}\text { mmoles/g } \\
0.764 \\
.680 \\
.535 \\
.365 \\
.258 \\
.175 \\
.113 \\
.057\end{array}$ & $\begin{array}{c}\text { mmoles/g } \\
0.108 \\
.198 \\
.197 \\
.145 \\
.104 \\
.069 \\
.035 \\
.018\end{array}$ & \begin{tabular}{c} 
mmoles/g \\
0.241 \\
.252 \\
.238 \\
.166 \\
.114 \\
\hdashline \\
\end{tabular} & $\begin{array}{c}\text { mmoles/g } \\
0.169 \\
.229 \\
.214 \\
.154 \\
.107 \\
.069 \\
.035 \\
.016\end{array}$ & $\begin{array}{c}\text { mmoles/g } \\
0.160 \\
.242 \\
.247 \\
.187 \\
.137 \\
.095 \\
.062 \\
.036\end{array}$ & $\begin{array}{c}\text { mmoles/g } \\
0.144 \\
.214 \\
.212 \\
.154 \\
.107 \\
.069 \\
.035 \\
.018\end{array}$ \\
\hline
\end{tabular}

Although all of the methods of calculation are based on forms of the same equation ( $\mathrm{eq} 2^{\prime}$ ), it is not a foregone conclusion that they must necessarily yield idential values, since the experimental quantities used in each calculation are different. Thus, the values listed in the second column of table 4 made no use of the $\mathrm{pH}$, of the total amount bound, nor of the initial amounts of acid present; those listed in the remaining columns made no use of the residual concentrations of the two anions at equilibrium. Those listed in the fourth column made no use of the affinity constant of the dye anion. All of these several quantities are interrelated if the theory is correct; the extent to which they are found to be consistent renders support to the theoretical conception behind them.

In table 5, similar calculations are carried out for the data obtained with unequal amounts of the acids, but only eq 5 and 6 have been used. The calculations are limited to a range of $\mathrm{pH}$ values in which no appreciable decomposition of the wool occurred. The theoretical 
curves in figure 2 of an earlier paper represent these calculations. Calculations with the other methods have been omitted, partly because data were not obtained which were adequate for the application of eq 3, owing to the small amount of dye left in solution.

In calculating the data given in table 4 , the combination of acid by the small amount of histidine present in wool was taken into account in the simplest way possible by considering it to be quantitatively combined with the anion of highest affinity. Accordingly the amount of acid combined with the carboxyl groups was then calculated by the equation previously given, on the basis of 0.79 $\mathrm{mmole} / \mathrm{g}$ maximum instead of 0.82 , and $0.03 \mathrm{mmole} / \mathrm{g}$ of the dye was added to the resulting amount of the predicted dye bound. This procedure was not followed in calculating the values for table 5, because the larger proportion present of the anion of lower affinity should result in a more even distribution of the two anions bound when back-titrating histidine as well as when back-titrating the carboxyl groups. It therefore appears reasonable to achieve an approximation by considering the amount combined as if it were_a function of one homogeneous set of groups.

TABLE 5.-Comparison of further data obtained with mixtures of acids, with theoretically calculated values

\begin{tabular}{|c|c|c|c|}
\hline \multirow{2}{*}{$\mathrm{pH}$} & \multirow{2}{*}{$\begin{array}{l}\text { Total } \\
\text { amount } \\
\text { of acid } \\
\text { bound }\end{array}$} & \multicolumn{2}{|c|}{$\begin{array}{l}\text { Amount of colorless or } \\
\text { "second" anion bound }\end{array}$} \\
\hline & & $\begin{array}{l}\text { Experi- } \\
\text { mental }\end{array}$ & $\begin{array}{c}\text { Calculated } \\
\text { by eq } \\
5 \text { or } 6\end{array}$ \\
\hline \multicolumn{4}{|c|}{ A. Hydrochloric acid and Orange II (10:1) } \\
\hline $\begin{array}{l}1.40 \\
1.58 \\
1.80 \\
1.98 \\
2.20 \\
2.46 \\
2.78 \\
3.26\end{array}$ & $\begin{array}{c}\text { mmoles/g } \\
0.785 \\
.733 \\
.650 \\
.562 \\
.456 \\
.341 \\
.223 \\
.092\end{array}$ & $\begin{array}{c}\text { mmoles } g \\
0.304 \\
.396 \\
.428 \\
.408 \\
.350 \\
.273 \\
.184 \\
.073\end{array}$ & $\begin{array}{c}\text { mmoles/g } \\
0.244 \\
.372 \\
.414 \\
.413 \\
.362 \\
.279 \\
.187 \\
.078\end{array}$ \\
\hline \multicolumn{4}{|c|}{$\begin{array}{l}\text { B. Naphthalenesulfonic Acid and Orange II } \\
\qquad(10: 1)\end{array}$} \\
\hline $\begin{array}{l}2.14 \\
2.47 \\
2.85 \\
3.30\end{array}$ & $\begin{array}{r}0.781 \\
.684 \\
.524 \\
.304\end{array}$ & $\begin{array}{r}0.643 \\
.589 \\
.463 \\
.273\end{array}$ & $\begin{array}{r}0.512 \\
.569 \\
.459 \\
.272\end{array}$ \\
\hline
\end{tabular}

\section{ESTIMATION OF ANION AFFINITIES FROM EXPERIMENTS WITH MIXTURES}

One value in demonstrating that the experiments with mixtures of acids are in harmony with the concept of anion-protein association lies in the ensuing practical possibility of calculating the affinities for wool, $1 / K_{\mathrm{A}}{ }^{\prime}$, of anions of high affinity, from such experiments. When such anions are under investigation, the $\mathrm{pH}$ values at the midpoints of titration curves obtained with their acids are high owing to almost quantitative transier of the acid to the fibers. The disadvantages 
of working with such extremely unbuffered solutions are well known: the presence of even small traces of the more common acidic impurities, such as hydrochloric or sulfuric acid, which remain partly uncombined, may result in fortuitously low $\mathrm{pH}$ values |5]. In mixture experiments, the addition of equivalent amounts of acids of lower affinity for wool brings the entire titration curve into a more convenient region of low $\mathrm{pH}$ values; likewise the presence of known amounts of the second acid minimizes the effect of the presence of traces of other impurities.

Numerous methods are available for calculating $K_{2}^{\prime}$ from $K_{1}{ }^{\prime}$, depending on which of the other experimental variables are known. The simplest of these is based on eq 3, which requires only knowledge of the amounts of the two anions taken up at equilibrium, and of the amounts leit in solution. Only two sets of experiments given in tables 1 and 2 contain sufficient data at amounts of total acid bound well under $0.8 \mathrm{mmole} / \mathrm{g}$ to permit calculation of the ratio $K_{2}^{\prime} / K_{1}{ }^{\prime}$ with this equation (table 6 ). It appears that the value obtained in the presence of chloride, the anion of low affinity, may be more reliable than the value obtained with the anion which offers greater competition. This result appears also when other methods are used.

TABLE 6.-Calculation of $K_{2}^{\prime}$ (Orange II-wool dissociation constant) from mixture data

\begin{tabular}{|c|c|c|c|c|}
\hline $\begin{array}{l}\text { Total } \\
\text { acid } \\
\text { bound }\end{array}$ & $\begin{array}{l}\text { Experi- } \\
\text { mental } \\
\text { ratio of } \\
\text { amounts } \\
\text { bound }\end{array}$ & $\left(\frac{a_{1}}{a_{2}}\right)^{1 / 2}$ & $\frac{K_{2}^{\prime}}{K_{1}^{\prime}}$ & $\begin{array}{l}K_{2}^{\prime} \text { cal- } \\
\text { culated }\end{array}$ \\
\hline \multicolumn{5}{|c|}{ A. Naphthalenesulfonic acid (1:1) } \\
\hline \multirow[t]{2}{*}{$\begin{array}{r}0.680 \\
.535 \\
.365 \\
.258\end{array}$} & \multirow[t]{2}{*}{$\begin{array}{r}0.410 \\
.582 \\
.634 \\
.675\end{array}$} & \multirow[t]{2}{*}{$\begin{array}{l}6.06 \\
8.53 \\
9.04 \\
9.74\end{array}$} & \multirow[t]{2}{*}{$\begin{array}{r}0.00458 \\
.00466 \\
.00524 \\
.00480\end{array}$} & $\begin{array}{r}0.000096 \\
.000097 \\
.000109 \\
.000100\end{array}$ \\
\hline & & & & $\begin{array}{l}\text { avg. } \\
0.000103 \\
-\log K_{2}^{\prime}= \\
3.99\end{array}$ \\
\hline \multicolumn{5}{|c|}{ B. Hydrochloric acid (10:1) } \\
\hline 0.735 & 1. 392 & 77.5 & 0.000324 & $\begin{array}{r}0.000170 \\
-\log K_{2}^{\prime}= \\
{ }^{*} 3.77\end{array}$ \\
\hline
\end{tabular}

*The value of $-\log K_{2}^{\prime}$ previously found was 3.64 [5].

\section{MIXTURES OF A DYE SALT AND AN ACID}

Two sets of data obtained with the sodium salt of Orange II, with hydrogen ions furnished in one case by hydrochloric acid and in the other by naphthalenesulfonic acid, are given in table 3 . The essential feature of these data is the closeness with which they parallel data obtained with the pure dye acid [6]. This similarity depends very critically on maintaining an exact equivalence between the two components of the mixture: if even small excess amounts of acid are present, considerably lower $\mathrm{pH}$ values are found, because the $\mathrm{pH}$ is then largely determined by the excess amount of acid of relatively low 
affinity. This fall in $\mathrm{pH}$ results in a further separation of the results obtained with the dye salt plus hydrochloric acid from those obtained with the dye acid itself. With dye salt plus naphthalenesulfonic acid, however, a slight inequality of acid and salt has a smaller effect. The anion of the latter itself combines with wool to a measurable extent, even at the high $\mathrm{pH}$ values which characterize the curve for the dye, and thus a larger fraction of the excess hydrogen ions is combined.

Chloride, unlike naphthalenesulfonate, competes with the dye anion so ineffectively that it is not combined to a measurable extent. In fact the difference between the position of the hydrochloric acid dye curve and the position of the curve for the dye alone may be attributed to the presence of cations other than hydrogen $\left(\mathrm{Na}^{+}\right)$, rather than to the presence of a competing anion. Owing to the high tendency of dye anions to combine with wool, the fiber acquires a negative charge, which in this case can be neutralized by sodium ions as well as by hydrogen ions. Thus some sodium ions combine with the fiber in place of hydrogen ions, leaving the solution slightly more acid than when the same amount of dye is taken up from solutions of dye acid. Some sodium ion is also taken up from mixtures of the dye salt with naphthalenesulfonic acid; here, however, combination with naphthalenesulfonate also occurs (table $3, \mathrm{~B}$ ) and the net result is a decrease in acidity.

An approximate equation for mixtures, which relates the $\mathrm{pH}$ at which half the maximum amount of acid is combined to the degree of exhaustion of the dye from the solution, may be developed by rewriting eq $2^{\prime}$ and eliminating $a_{1}$ by setting it equal to $\left[\mathrm{H}^{+}\right]+\left[\mathrm{Na}^{+}\right]-\left[\mathrm{A}_{2}\right]$ :

$$
\frac{\rho\left(K_{2}^{\prime}\right)^{1 / 2}}{\left(\left[\mathrm{H}^{+}\right]+\left[\mathrm{Na}^{+}\right]-\left[\mathrm{A}_{2}\right]\right)^{1 / 2}+\rho\left[\mathrm{A}_{2}\right]^{1 / 2}} f\left(\boldsymbol{a}_{\mathrm{H}}\right)^{\prime}=1,
$$

where $\boldsymbol{a}_{\mathrm{H}}$ represents the activity of hydrogen ion at which half the maximum amount of acid is combined. This may be simplified by considering that the quantity $\left[\mathrm{Na}^{+}\right]-\left[\mathrm{A}_{2}\right]$, hereafter written $\delta$, is equal to the difference between the dye taken up and sodium taken up, and that $\delta$ is so much larger than $\left[\mathrm{H}^{+}\right]$at the midpoint of the curves that no significant error is caused by writing $\delta$ for $\left[\mathrm{H}^{+}\right]+\delta$. These substitutions and rearrangement of terms give

$$
\frac{K_{2}^{1 / 2}}{\frac{\delta^{1 / 2}}{\rho}+\left[\mathrm{A}_{2}\right]^{1 / 2}} \cdot \frac{\boldsymbol{a}_{\mathrm{H}}^{1 / 2}+\left(K_{\mathrm{H}}\right)^{1 / 2}}{\boldsymbol{a}_{\mathrm{H}}^{1 / 2}+\left(K_{\mathrm{H}}\right)^{1 / 2}}=1 .
$$

In both cases under consideration in this paper, $\delta^{1 / 2} / \rho$ is always very much smaller than $\left[\mathrm{A}_{2}\right]^{1 / 2}$, and may be neglected in a first approximation. The resulting approximate expression,

$$
\frac{K_{2}^{1 / 2}}{\left[\mathrm{~A}_{2}\right]^{1 / 2}} \cdot \frac{\boldsymbol{a}_{\mathrm{H}}{ }^{1 / 2}+\left(K_{\mathrm{H}}\right)^{1 / 2}}{\boldsymbol{a}_{\mathrm{H}}^{1 / 2}+\left(K_{\mathrm{H}}\right)^{1 / 2}}=1
$$

is identical with the exact relation that holds for titration with a single acid (eq $1^{\prime \prime}$, with $a_{\mathrm{H}}=a_{2}$ ). Unlike the latter, however, $\left[\mathrm{A}_{2}\right]$ is not necessarily equal to $\left[\mathrm{H}^{+}\right]$. Thus the equation shows that acids such as hydrochloric, which reduce $\left[\mathrm{A}_{2}\right]$ below the value characteristic of titration with the pure dye acid (increasing the exhaustion of the bath), give a curve of combination the midpoint of which lies 
at lower $\mathrm{pH}$ values than that obtained with the dye acid; and that the opposite is true for an acid which diminishes the exhaust, such as naphthalenesulfonic. These qualitative conclusions are confirmed experimentally. Unfortunately, neither eq $7^{\prime \prime}$ nor $7^{\prime}$ can be applied for a direct determination of $\bar{K}_{2}^{\prime}$, because of the great sensitivity of the calculated values to error in the measurement of the dye left uncombined, a quantity which it is more difficult to determine with high accuracy the more highly exhausted is the solution. In all of the experiments, a small part of the acid added is neutralized by base combined with the fibers as ash; this loss of acidity affects the exhaustion of dye to an appreciable extent when the exhaust is very high, and the dye leit uncombined is always higher than that predicted by the simple theory presented here.

It thus appears that whenever, for reasons of convenience it is desired to work with a dye salt rather than a dye acid, fairly accurate estimates of the affinity of its anion for wool may be obtained if the estimate is based on experiments in which a strong acid of especially low affinity, such as hydrochloric acid, is added to solutions of the dye salt in exactly equivalent amounts. If the latter condition is observed, the $\mathrm{pH}$ values found at a given degree of combination of the dye will be only slightly lower than those obtained with the dye acid. Attempts to calculate more closely the position of the curve for the dye acid itself by taking into account the degree of exhaustion of the dye, as in the equations above, are likely to lead to results of lower accuracy than estimates of the minimal affinity made in. this simple way.

\section{REFERENCES}

[1] J. Steinhardt, Ann. N. Y. Acad. Sci. 41, 287 (1941).

[2] J. Steinhardt, J. Research NBS \$8, 191 (1942) RP1452.

[3] J. Steinhardt and M. Harris, J. Research NBS 24, 335 (1940) RP1286; Am. Dyestuff Reptr. 29, 103 (1940); Textile Research 10, 181 (1940).

[4] J. Steinhardt, C. H. Fugitt, and M. Harris, J. Research NBS 26, 193 (1941) RP1377; Am. Dyestuff Reptr. 30, 223 (1941); Textile Research 11, 259 (1941).

[5] J. Steinhardt, C. H. Fugitt, and M. Harris, J. Research NBS 28, 201 (1942) RP1453; Am. Dyestuff Reptr. 31, 77 (1942).

[6] J. Steinhardt, C. H. Fugitt, and M. Harris, J. Research NBS 99, 417 (1942) RP1510.

Washington, June 4, 1942. 